\title{
Male Reproductive Health and Prostate Cancer Risk
}

\author{
Thomas J. Walsh, MD, MS \\ Department of Urology, University of Washington School of Medicine, Seattle, WA
}

\begin{abstract}
Purpose of review-Male infertility impacts a substantial proportion of men and has serious implication for a man's quality of life. Advances in reproductive technology may allow men to bypass urologic care in order to achieve their family planning goals. Recent data suggests that male reproductive failure may be a harbinger of future urologic diseases, including prostate cancer, thus emphasizing the importance of dedicated urologic evaluation and care for all male infertility patients.
\end{abstract}

Recent findings-We will review the epidemiologic data that explores an association between male reproductive health and prostate cancer. We will review the potential biologic mechanisms that may underlie this association, and explore possible reasons for inconsistencies in study findings.

Summary-Studies of the association between male infertility and prostate cancer are inconsistent. Despite this, the association between reproductive health in a man's fourth decade (30s) and his development of aggressive prostate cancer in his sixth decade (50s) should not be ignored. These findings, combined with the robustness of the potential common underlying mechanisms, provide a foundation for future studies of male reproductive health that are more specific and directed in their approach to answering questions about the association between male reproductive failure and future systemic disease.

\section{Key Words/Phrases}

Male Infertility; Prostate Cancer; Men's Health; Risk Factors

\section{Male Infertility}

Infertility is defined as the failure to conceive despite one year of regular, unprotected intercourse. Approximately $15 \%$ of couples overall will experience infertility and this prevalence rises with advancing age. Of these couples, $20 \%$ will have a male factor that is solely responsible and male factors will contribute to an additional $30 \%$ of cases. [1-3]

With the advent of Assisted Reproductive Technologies (ART) pregnancy may be achieved in some cases without urologic expertise; however, clinically significant medical disease that underlies male infertility may be missed[4-6]. In a landmark study, Honig and colleagues studied more than a thousand infertile men and identified diseases that required intervention, including cancer, in ten cases (0.8\%).[3] Similarly, Kolettis evaluated 536 infertile men and identified $33(6 \%)$ with medical diseases, including cases of both prostate and testicular cancer.[7, 8] These findings initiated a new era of research focused on understanding the association between male infertility and malignancy.

Corresponding author: Thomas J. Walsh, MD, MS, Department of Urology, University of Washington School of Medicine, Health Sciences Building, 1959 NE Pacific, BB-1115, Box 356510, Seattle, WA 98195, Phone: 206-543-3640, Fax: 206-543-3272, walsht@uw.edu. 
It is now accepted that male reproductive failure may precede testicular germ cell cancer by up to a decade and new insights regarding the association between male infertility and other oncologic disease have materialized [2,9]. Given common disease pathways, recent attention has been placed on the association between male infertility and prostate cancer. The remainder of this review will focus on the epidemiologic data that links these diseases, the limitations in the data, and the potential biologic mechanisms that may underlie their association.

\section{Prostate Cancer Risk Factors}

To understand the importance of the link between male infertility and prostate cancer, some background is necessary. Prostate cancer $(\mathrm{CaP})$ is the most common malignancy diagnosed in men and the second most common cause of cancer related mortality in the U.S.; however, its etiology remains poorly understood[10,11]. The most agreed upon risk factors remain age, family history, and race[12].

The impact of race on CaP risk has been thoroughly investigated. Studies have demonstrated a relatively lower risk in Asia and higher risk in North American and Scandanavian countries. Interestingly, after emigration to western society, the protective effect conferred to men of Asian descent appears to be partially lost within a generation, suggesting a cultural difference in exposures that predisposes a man to develop CaP. Regardless of race, a positive family history has been found to consistently confer a higher risk of CaP[13].

Because of persistent limitations in our understanding of the risks for prostate cancer, new efforts have been made to explore novel factors that increase risk for this ubiquitous disease. These risk factors include genetic variation, prostate infection and inflammation, androgen and androgen receptor variants, nutrition, and reproductive health. [11, 12, 14-20]

\section{Epidemiologic data linking male reproductive health and prostate cancer}

Each of the following subsections will explore different measures of male reproductive health and prostate cancer risk

\section{Fatherhood and prostate cancer risk}

Table 1 provides a summary of the studies of association between paternity and prostate cancer. These studies were designed to explore theories that androgen sensitivity is common to both prostate cancer and fertility. [21] In 2002, Dennis and Dawson consolidated multiple studies of paternity and prostate cancer[22]. The primary risk factor of interest was prior sexually transmitted infections; however, this meta-analysis of 18 studies did not identify a statistically significant association between the number of offspring and $\mathrm{CaP}$. Giwercman and colleagues provided evidence from a cohort study of 48,850 Swedish men that childless men were $20 \%$ less likely to develop CaP compared to men with children (OR $0.83,95 \%$ CI 0.81-0.86).[23] A smaller study by Negri of 1,249 Italian men found no association between men with fewer or no children and $\mathrm{CaP}$, but highlighted the importance of controlling for key social factors such as marital status[24]. In a variation of this type of investigation, Harlap found that men with a history of fathering stillborn offspring were at higher risk of developing prostate cancer.[25]

Given these conflicting results, Jorgensen and colleagues performed the largest populationbased cohort study and reported on 51.6 million person-years of follow up among Danish men [21]. In this study, 3400 cases of prostate cancer were identified and childless men had a $16 \%$ relative reduction in $\mathrm{CaP}$ diagnoses (RR 0.84, 95\% CI 0.90-1.08), consistent with the findings of Giwercman. Interestingly, the authors found that among fathers, $\mathrm{CaP}$ risk was 
highest among those with the fewest children in a dose-response relationship, whereby with each additional child, $\mathrm{CaP}$ risk further decreased (Figure 1).[21]

Most recently, Eisenberg evaluated the relationship between offspring number and prostate cancer risk among 161,823 men enrolled in the National Institutes of Health-American Association of Retired Persons Diet and Health Study[26]. The study identified 8,134 cases of prostate cancer and found that overall there was no relationship between fatherhood and incident prostate cancer [hazard ratio (HR) 0.94, 95\% confidence interval (CI) 0.86-1.02]. However, after stratifying for prostate cancer screening, prostate-specific antigen (PSA) unscreened childless men had a lower risk of prostate cancer (HR 0.73, 95\% CI 0.58-0.91) compared with fathers. These data suggest a similar relationship between paternity and $\mathrm{CaP}$ among U.S. men (as seen in Danish and Swedish men) and emphasized the importance of assessing PSA screening when investigating prostate cancer risk.

\section{Offspring gender and prostate cancer risk}

Table 2 summarizes the studies of association between offspring gender and prostate cancer. Investigators first reported on the association or lack of association between offspring gender and CaP in the 1980s with mixed results[27-29]. Since that time, the deletion of Ychromosome specific genes have been implicated in the development of prostate cancer and in addition to their required for male sex determination Y-chromosome specific genes are a known cause of impaired spermatogenesis [30]. Harlap and colleagues hypothesized that that a Y chromosome locus might be common etiology for failure to father sons and $\mathrm{CaP}$. The authors utilized the Jewish Perinatal Cohort Study of 38,934 men and found that an absence of male offspring conferred a $40 \%$ increased risk (RR1.40, 95\% CI 1.04-1.91) for CaP. [31] Following a dose-response relationship, the fewer sons a man sired as a proportion of his total offspring, the higher his risk of cancer. Among all men who developed prostate cancer, mortality was highest among men who did not father sons, suggesting some degree of association with more aggressive cancers. In an effort to replicate the this data, Bermejo and colleagues reported on more than 3.1 million men of which 120,812 developed prostate. In this much larger study, the authors failed to find an association between offspring gender and prostate cancer risk[32]. Others have reported similar negative findings [33]

Eisenberg and colleagues reported the association between offspring gender and $\mathrm{CaP}$ in their study of U.S men[26]. Among men unscreened for prostate cancer with PSA, the inability to father daughters appeared to confer a week but statistically significant increased risk for $\mathrm{CaP}$.

\section{Male infertility and prostate cancer risk}

The results of studies of paternity and gender offspring have been inconsistent. Each of these studies relied upon a surrogate marker for male fertility, namely number or gender of offspring in the absence of a specific fertility evaluation. A man's ability to father children is intimately related to the fertility potential of his partner, his socioeconomic status and his personal choices and thus the number of children fathered may not accurately reflect a man's biologic fertility. Our group recently studied a U.S.-based cohort of men evaluated specifically for infertility and found an association between male factor infertility and prostate cancer.[9] We identified 22,562 men evaluated for infertility in California and determined their subsequent risk of prostate cancer by linking them to the statewide cancer registries after a median follow-up time of 11 years. Overall, men evaluated for infertility but not necessarily with male factors, did not have increased risk of cancer relative to the general population (SIR $0.9 ; 95 \% \mathrm{CI} 0.8,1.1$ ). When cancer was stratified by grade, risk was significantly higher for men with male factor infertility who developed high grade prostate cancers (SIR 2.0; 95\% CI 1.2, 3.0). In multivariate analyses, men with male factor infertility 
were not statistically significantly more likely to be diagnosed with low grade prostate cancer compared to those without (HR 1.5, 95\% CI 1.0, 2.3); however, they were nearly three times more likely to be diagnosed with high grade prostate cancer (HR 2.8, 95\% CI $1.5,5.0)$. These data suggest that male factor infertility may be an early and identifiable risk factor for clinically significant prostate cancer. Further, the difference in risk between low and high grade cancers suggests that prostate cancer screening alone does not account for the increased cancer risk. This apparent increased risk for high grade prostate cancer may offer some insight into findings from the Jerusalem Perinatal Cohort study: the higher mortality seen in men with prostate cancer who did not father sons.

\section{Mechanisms that may underlie the association between male reproductive health and prostate cancer}

\section{Infertility as a harbinger of future cancers}

From puberty onward, spermatogenesis requires rapid and organized cell division that is exquisitely sensitive to a variety of genetic, hormonal and environmental insults [34]. These same insults may place individuals at higher risk for the development of cancer. Because germ cell renewal and meiosis rapidly accelerates at a very young age, declines in spermatogenesis or abnormal sperm quality may be the first marker of insult, long before cancer is detected.[35] This section provides a brief survey of potential etiologies of the link between poor sperm quality and subsequent prostate cancer. To date, some of these etiologies remain hypothetical but provide a foundation for future research.

\section{Androgen levels and androgen receptor sensitivity}

Several lines of evidence support an association between androgen production, androgen sensitivity, male reproduction and prostate cancer.

\section{Testicular Dysgenesis Syndrome}

Multiple Danish studies have culminated in the Testicular Dysgenesis Syndrome (TDS).[3638] TDS theory relates environmental modulators, genetics, hormonal function and infertility in the development of testis cancer[38]. Because of the androgen sensitivity of the prostate gland, this theory has applicability to prostate cancer. TDS theory posits that certain male reproductive disorders such as cryptorchidism, hypospadias, infertility, and TGCT may be manifestations of a fundamental perturbation of gonadal development related to environmental toxin exposure and underlying genetic predisposition.[39] Because of abnormal gonadal function, androgen sensitive organs such as the prostate may not receive adequate differentiating signals during critical stages of development thereby increasing their risk for malignancy.[40-42]

\section{Androgen receptor CAG repeats}

Variations in the number of CAG repeats within the gene that codes for the androgen receptor (AR) have been described in association with both male infertility and prostate cancer. Mosaad and colleagues assessed AR CAG repeat expansion in Egyptian men evaluated for infertility and found differences between infertile and control groups. The authors reported a negative correlation between CAG repeat length and sperm count thereby validating the concept that long stretches of CAG repeat may be associated with derangement of sperm production, presumably via decreased AR function.[43-47] Data associating androgen receptor $\mathrm{CAG}$ repeats with prostate cancer have been inconsistent but several studies have linked variation in $\mathrm{CAG}$ repeat length to clinically aggressive $\mathrm{CaP}$. [48$52]$ 


\section{Prostosomes}

Prostasomes are small membrane-bound vesicles produced within prostate acini that fuse with and transfer proteins to sperm whereby they modulate sperm motility and function. In the presence of prostasomes, sperm motility is increased, premature acrosome reactions are prevented and sperm integrity is preserved during transit through the female reproductive tract, thus they likely play a key role in male fertility[53]. Prostasomes have also been proposed as an etiologic factor in prostate cancer. The mechanism by which they contribute to malignant transformation is unclear; however, potential mechanisms include the promotion of tumor angiogenesis, cell cycle dysregulation and immunoprotection of malignantly transformed cells.[54]

\section{DNA mismatch repair}

The mismatch repair system is a DNA repair mechanism that corrects mispaired bases during DNA replication errors. Cancer cells deficient in MMR proteins have a $10^{2}$ to $10^{3}$ fold increase in the mutation rate. Defective DNA repair has previously been described in association with particular cancers, namely non-polyposis colon cancer, retinoblastoma and melanoma, and is suspected to play a role in certain gastric, breast and ovarian cancers.[35, $43,55-57]$ Work by Suter and colleagues found that epimutations of the DNA mismatch repair gene MLH1 may be present in both somatic and germ cells among select men with non-polyposis colorectal cancer. [35]

Data from studies of mice suggests that mutations in genes needed for DNA repair (PMS2, Mlh1) also lead to infertility characterized by meiotic arrest, a phenomenon that has also been observed in infertile men with azoospermia.[58-67] To date, soma - wide mutations of DNA mismatch repair genes have not been described in this population of men. More recently, similar genetic aberrations have been described for prostate cancer, whereby polymorphisms of the mismatch repair gene MSH3 and elevated levels of the mismatch repair protein PSM2 and have been associated with prostate cancer and with biochemical recurrence of prostate cancer after radical prostatectomy.[68, 69] Thus transcriptional mismatch repair errors in both germ-line DNA and somatic cell DNA could stem from one source and provide a biologic explanation for the link between $\mathrm{CaP}$ and male infertility.

\section{Y-Chromosome}

Abnormalities of the $\mathrm{Y}$ chromosome have been proposed to underlie the association between infertility and prostate cancer [30,31, 70-73]. The deletion of genes from the Ychromosome is one of the most well studied genetic causes of abnormal sperm production in men[74]. Y microdeletions occur in 6 to $8 \%$ of severely oligozoospermic men and in 3-15\% of azoospermic men, thus $\mathrm{Y}$ microdeletions are the most common molecularly defined cause of male infertility [75-77].

Advances in positional cloning studies have identified most of the genes on the human $Y$ chromosome, and have provided a resource for studying the expression of its genes in prostate cancer. Lau and colleagues examined the expression of the $\mathrm{Y}$ chromosome genes in a panel of prostate samples from men with benign prostatic hyperplasia (BPH), low and/or high grade carcinoma, and the prostatic cell line, $\mathrm{LNCaP}$, stimulated by androgen treatment[78]. Results from this study revealed heterogeneous and differential expression patterns of the $\mathrm{Y}$ chromosome genes that raise the possibility that some of these genes are either involved in or are affected by the oncogenic processes of the prostate. The up- and down-regulation of several Y chromosome genes by androgen suggest that they may play a role(s) in the hormonally stimulated proliferation of prostate cancer cells. 


\section{Epigenetic regulation}

Epigenetics is the study of changes produced in gene expression caused by mechanisms other than changes in the underlying DNA sequence. Examples of such changes might be DNA methylation or histone deacetylation, both of which serve to suppress gene expression without altering the sequence of the silenced genes. These changes may remain through cell divisions for the remainder of the cell's life and may also last for multiple generations. However, there is no change in the underlying DNA sequence of the organism.

Recent data indicates that epigenetic may link infertility and CaP.[79] Multiple studies have reported the detrimental impact of epimutations on spermatogenesis. Rajender and colleagues recently reviewed the available literature and found strong evidence that epigenetic aberrations are associated with poor semen quality and male infertility and may be significantly impacted by environmental factors [80].

Similar epigenetic mechanisms have been implicated in the development of multiple cancers, including prostate cancer [35, 81, 82]. Aberrant DNA methylation (hypo- and hypermethylation) is the best-characterized alteration in $\mathrm{CaP}$ and leads to genomic instability and inappropriate gene expression[83]. Global and locus-specific changes in chromatin remodeling are implicated in $\mathrm{CaP}$, with evidence suggesting a causative dysfunction of histone-modifying enzymes. MicroRNA deregulation also contributes to prostate carcinogenesis, including interference with androgen receptor signaling and apoptosis.

Importantly, environmental toxins/drugs may affect fertility and cancer risk via epigenetic modifications and this may account for the simultaneous impact of environment factors on both reproductive health and cancer risk. For example, 5-aza-2'-deoxycytidine, an anticancer agent, has been shown to cause a decrease in global DNA methylation that leads to altered sperm morphology, decreased sperm motility, decreased fertilization capacity, and decreased embryo survival. Similarly, endocrine disruptors, such as methoxychlor (an estrogenic pesticide) and vinclozolin (an anti-androgenic fungicide) have been found by experiments on animals to affect epigenetic modifications that may cause spermatogenic defects and poor prostate health in subsequent generations[84].

\section{Environmental exposures}

While multiple environment toxicants have been implicated as causative factors for both poor spermatogenesis and prostate cancer, perhaps the best described agents are those that mimic the effects of estrogens, so called phyto-estrogens and xeno-estrogens. A significant body of toxicology data suggests that exposure to certain endocrine disrupters is associated with reproductive toxicity, including (1) abnormalities of the male reproductive tract (cryptorchidism, hypospadias), (2) reduced semen quality, and (3) impaired fertility in the adult[85].

Similarly, given the hormonal sensitivity of the prostate gland, there is increasing evidence both from epidemiology studies and animal models that specific endocrine-disrupting compounds may have impact on prostate cancer risk. These effects may be linked to interference with estrogen signaling and altered estrogen levels within the body. Epidemiologic evidence links specific pesticides, PCBs and inorganic arsenic exposures to elevated prostate cancer risk. Animal studies demonstrate augmentation of prostate carcinogenesis with several other environmental estrogenic compounds including cadmium, UV filters and BPA. There is increased sensitivity of the prostate to these endocrine disruptors during development, such that during the in utero and neonatal period as well as during puberty, individuals are particularly vulnerable. [86]. Adult exposure also has impact 
as $\mathrm{Xu}$ and colleagues recently reported a significant association between serum levels of organochlorine pesticides and prevalent prostate cancer[87].

\section{Reconciling differences in study findings}

The compiled epidemiologic data are heterogeneous and as a result, a clear picture of how a man's reproductive health may predict his risk for cancer has not yet emerged. Differences in the finding of these studies likely arise from multiple sources. The most important difference is in the definition of both the exposure, a male reproductive event, and in the outcome, prostate cancer.

With regard to defining the exposures of interest, the number of children a man has fathered may not, in all cases, be an accurate reflection of his reproductive biology. While each of these "reproductive events": paternity, offspring gender and biologic infertility may be individual predictors of prostate cancer (or protection against a future cancer) the mechanisms through which each predictor is etiologically related to cancer may not be the same. Thus, each of these factors may provide a unique window into the future prostate health of man and should not be discounted.

Disparities in study findings also result from differences in the assessment of outcome, namely, prostate cancer. Data from large observational cohorts of men diagnosed with prostate cancer have identified a subset of men at very low risk for prostate-cancer specific mortality during their lifetime and autopsy studies have described the occurence of clinically indolent prostate cancer in men dying of other causes.[88-90] Because of these aspects of prostate cancer, it is feasible that we are dealing with two distinct diseases: low grade prostate cancer which is indolent, and high grade prostate cancer which is potentially life threatening. Prostate cancer risk factor studies should be aimed at identifying predictors of high risk disease, in young men who are most likely to benefit from aggressive therapy. Further, it should be expected that predictors of "all" prostate cancer, of which $2 / 3 \mathrm{rds}$ is low grade, may not be the same as the predictors of isolated high grade cancer.

In spite of these highly varied findings, the association between male reproductive health in a man's fourth decade (30s) and his development of aggressive prostate cancer in his sixth decade (50s) should not be ignored. Rather these findings, combined with the robustness of the potential common underlying mechanisms, should serve as the foundation of future longitudinal studies of male reproductive health that are more specific and directed in their approach to answering questions about the association between male reproductive failure and future systemic disease.

\section{Key Conclusions}

1. The sensitivity of male gametes may make infertility a harbinger of other medical diseases, including prostate cancer.

2. Epidemiologic data relating male reproductive events to prostate cancer risk is mixed but provides strong impetus for additional research.

3. Current advances in molecular genetics and epigenetics may allow a deeper understanding of the mechanisms driving these linkages and ultimately lead to new interventions and predictive models for assessing prostate cancer risk.

\section{References}

1. Velez de la Calle JF, Rachou E, le Martelot MT, et al. Male infertility risk factors in a French military population. Hum Reprod. 2001; 16:481-6. [PubMed: 11228215] 
*2. Walsh TJ, Croughan MS, Schembri M, et al. Increased risk of testicular germ cell cancer among infertile men. Arch Intern Med. 2009; 169:351-6. First prospective U.S. Cohort study to demonstrate that male infertility is a risk factor for the future development of testicular germ cell cancer. [PubMed: 19237718]

3. Honig SC, Lipshultz LI, Jarow J. Significant medical pathology uncovered by a comprehensive male infertility evaluation. Fertil Steril. 1994; 62:1028-34. [PubMed: 7926114]

4. Ziebe S, Devroey P. Assisted reproductive technologies are an integrated part of national strategies addressing demographic and reproductive challenges. Hum Reprod Update. 2008; 14:583-92. [PubMed: 18786951]

5. Palermo G, Joris H, Devroey P, Van Steirteghem AC. Pregnancies after intracytoplasmic injection of single spermatozoon into an oocyte. Lancet. 1992; 340:17-8. [PubMed: 1351601]

6. Sherins RJ, Thorsell LP, Dorfmann A, et al. Intracytoplasmic sperm injection facilitates fertilization even in the most severe forms of male infertility: pregnancy outcome correlates with maternal age and number of eggs available. Fertil Steril. 1995; 64:369-75. [PubMed: 7615116]

7. Kolettis PN, Sabanegh ES. Significant medical pathology discovered during a male infertility evaluation. J Urol. 2001; 166:178-80. [PubMed: 11435851]

8. Sigman M, Jarow JP. Endocrine evaluation of infertile men. Urology. 1997; 50:659-64. [PubMed: 9372871]

**9. Walsh TJ, Schembri M, Turek PJ, et al. Increased risk of high-grade prostate cancer among infertile men. Cancer. 116:2140-7. Important, hypothesis generating first evidence that impaired male fertility may be an early marker for future high grade prostate cancer. [PubMed: 20309846]

10. Surveillance E, and End Results (SEER) Program. SEER*Stat Database: Incidence - SEER 9 Regs Public-Use. Nov. 2004 Sub

11. Bostwick DG, Burke HB, Djakiew D, et al. Human prostate cancer risk factors. Cancer. 2004; 101:2371-490. [PubMed: 15495199]

12. Gronberg H. Prostate cancer epidemiology. Lancet. 2003; 361:859-64. [PubMed: 12642065]

13. Whittemore AS, Wu AH, Kolonel LN, et al. Family history and prostate cancer risk in black, white, and Asian men in the United States and Canada. Am J Epidemiol. 1995; 141:732-40. [PubMed: 7535977]

14. Monroe KR, Yu MC, Kolonel LN, et al. Evidence of an X-linked or recessive genetic component to prostate cancer risk. Nat Med. 1995; 1:827-9. [PubMed: 7585188]

15. Stattin P, Bylund A, Rinaldi S, et al. Plasma insulin-like growth factor-I, insulin-like growth factor-binding proteins, and prostate cancer risk: a prospective study. J Natl Cancer Inst. 2000; 92:1910-7. [PubMed: 11106682]

16. Zheng SL, Sun J, Wiklund F, et al. Cumulative association of five genetic variants with prostate cancer. N Engl J Med. 2008; 358:910-9. [PubMed: 18199855]

17. Klein EA, Silverman R. Inflammation, infection, and prostate cancer. Curr Opin Urol. 2008; 18:315-9. [PubMed: 18382242]

18. Lu Y, Sun J, Kader AK, et al. Association of prostate cancer risk with snps in regions containing androgen receptor binding sites captured by ChIP-On-chip analyses. Prostate.

19. Crowe FL, Key TJ, Appleby PN, et al. Dietary fat intake and risk of prostate cancer in the European Prospective Investigation into Cancer and Nutrition. Am J Clin Nutr. 2008; 87:1405-13. [PubMed: 18469265]

20. Allen NE, Key TJ, Appleby PN, et al. Animal foods, protein, calcium and prostate cancer risk: the European Prospective Investigation into Cancer and Nutrition. Br J Cancer. 2008; 98:1574-81. [PubMed: 18382426]

21. Jorgensen KT, Pedersen BV, Johansen C, Frisch M. Fatherhood status and prostate cancer risk. Cancer. 2008; 112:919-23. [PubMed: 18181100]

22. Dennis LK, Dawson DV. Meta-analysis of measures of sexual activity and prostate cancer. Epidemiology. 2002; 13:72-9. [PubMed: 11805589]

23. Giwercman A, Richiardi L, Kaijser M, et al. Reduced risk of prostate cancer in men who are childless as compared to those who have fathered a child: a population based case-control study. Int J Cancer. 2005; 115:994-7. [PubMed: 15729731] 
24. Negri E, Talamini R, Bosetti C, et al. Risk of prostate cancer in men who are childless. Int J Cancer. 2006; 118:786-7. author reply 788. [PubMed: 16114016]

**25. Harlap S, Friedlander Y, Barchana M, et al. Late fetal death in offspring and subsequent incidence of prostate cancer in fathers: the Jerusalem Perinatal Study cohort. Prostate. 2007; 67:989-98. Largest population-based cohort study to find and association between paternity and prostate cancer. [PubMed: 17440938]

26. Eisenberg ML, Park Y, Brinton LA, et al. Fatherhood and incident prostate cancer in a prospective US cohort. Int J Epidemiol. 40:480-7. [PubMed: 20959354]

27. Le Marchand L, Yoshizawa CN, Kolonel LN. Sex ratio of offspring of patients with prostatic cancer. CMAJ. 1986; 135:107. [PubMed: 3719494]

28. Hill GB, Fincham SM, Wijayasinghe C, et al. Sex ratio of offspring of patients with prostatic cancer. CMAJ. 1985; 133:567-71. [PubMed: 4027827]

29. Spitz MR, Berman EL, Newell GR, von Eschenbach AC. Sex ratio of offspring of patients with prostatic cancer. CMAJ. 1986; 134:104-5. [PubMed: 3942907]

30. Perinchery G, Sasaki M, Angan A, et al. Deletion of Y-chromosome specific genes in human prostate cancer. J Urol. 2000; 163:1339-42. [PubMed: 10737540]

31. Harlap S, Paltiel O, Friedlander Y, et al. Prostate cancer in fathers with fewer male offspring: the Jerusalem Perinatal Study cohort. J Natl Cancer Inst. 2007; 99:77-81. [PubMed: 17202115]

32. Bermejo JL, Sundquist J, Hemminki K. Re: Prostate cancer in fathers with fewer male offspring: the Jerusalem Perinatal Study cohort. J Natl Cancer Inst. 2007; 99:901-2. author reply 903-4. [PubMed: 17551156]

33. James WH. Re: Prostate cancer in fathers with fewer male offspring: the Jerusalem Perinatal Study cohort. J Natl Cancer Inst. 2007; 99:902. author reply 903-4. [PubMed: 17551157]

34. Walker WH. Molecular mechanisms of testosterone action in spermatogenesis. Steroids. 2008

35. Suter CM, Martin DI, Ward RL. Germline epimutation of MLH1 in individuals with multiple cancers. Nat Genet. 2004; 36:497-501. [PubMed: 15064764]

36. Skakkebaek NE, Jorgensen N, Main KM, et al. Is human fecundity declining? Int J Androl. 2006; 29:2-11. [PubMed: 16466518]

37. Skakkebaek NE, Rajpert-De Meyts E, Jorgensen N, et al. Testicular cancer trends as 'whistle blowers' of testicular developmental problems in populations. Int J Androl. 2007; 30:198-204. discussion 204-5. [PubMed: 17705804]

38. Skakkebaek NE, Rajpert-De Meyts E, Main KM. Testicular dysgenesis syndrome: an increasingly common developmental disorder with environmental aspects. Hum Reprod. 2001; 16:972-8. [PubMed: 11331648]

39. Olesen IA, Sonne SB, Hoei-Hansen CE, et al. Environment, testicular dysgenesis and carcinoma in situ testis. Best Pract Res Clin Endocrinol Metab. 2007; 21:462-78. [PubMed: 17875492]

40. Masters JR, Koberle B. Curing metastatic cancer: lessons from testicular germ-cell tumours. Nat Rev Cancer. 2003; 3:517-25. [PubMed: 12835671]

41. Spierings DC, de Vries EG, Vellenga E, de Jong S. The attractive Achilles heel of germ cell tumours: an inherent sensitivity to apoptosis-inducing stimuli. J Pathol. 2003; 200:137-48. [PubMed: 12754734]

42. Einhorn EH. Testicular cancer: an oncological success story. Clin Cancer Res. 1997; 3:2630-2. [PubMed: 10068265]

43. Krausz C, Forti G, McElreavey K. The Y chromosome and male fertility and infertility. Int J Androl. 2003; 26:70-5. [PubMed: 12641824]

44. Krausz C, Forti G. The Y chromosome and its fragility. Int J Androl. 2008; 31:374-5. [PubMed: 18644091]

45. Krausz C, Quintana-Murci L, Forti G. Y chromosome polymorphisms in medicine. Ann Med. 2004; 36:573-83. [PubMed: 15768829]

46. Rajpert-De Meyts E. Developmental model for the pathogenesis of testicular carcinoma in situ: genetic and environmental aspects. Hum Reprod Update. 2006; 12:303-23. [PubMed: 16540528]

47. Mosaad YM, Shahin D, Elkholy AA, et al. CAG repeat length in androgen receptor gene and male infertility in Egyptian patients. Andrologia. 
48. Rodriguez-Gonzalez G, Cabrera S, Ramirez-Moreno R, et al. Short alleles of both GGN and CAG repeats at the exon- 1 of the androgen receptor gene are associated to increased PSA staining and a higher Gleason score in human prostatic cancer. J Steroid Biochem Mol Biol. 2009; 113:85-91. [PubMed: 19095061]

49. Silva Neto B, Koff WJ, Biolchi V, et al. Polymorphic CAG and GGC repeat lengths in the androgen receptor gene and prostate cancer risk: analysis of a Brazilian population. Cancer Invest. 2008; 26:74-80. [PubMed: 18181049]

50. Das K, Cheah PY, Lim PL, et al. Shorter CAG repeats in androgen receptor and non-GG genotypes in prostate-specific antigen loci are associated with decreased risk of benign prostatic hyperplasia and prostate cancer. Cancer Lett. 2008; 268:340-7. [PubMed: 18495332]

51. Mittal RD, Mishra D, Mandhani AK. Role of an androgen receptor gene polymorphism in development of hormone refractory prostate cancer in Indian population. Asian Pac J Cancer Prev. 2007; 8:275-8. [PubMed: 17696745]

52. Giwercman C, Giwercman A, Pedersen HS, et al. Polymorphisms in genes regulating androgen activity among prostate cancer low-risk Inuit men and high-risk Scandinavians. Int J Androl. 2008; 31:25-30. [PubMed: 17376218]

53. Ronquist G, Nilsson BO. The Janus-faced nature of prostasomes: their pluripotency favours the normal reproductive process and malignant prostate growth. Prostate Cancer Prostatic Dis. 2004; 7:21-31. [PubMed: 14999234]

54. Burden HP, Holmes CH, Persad R, Whittington K. Prostasomes--their effects on human male reproduction and fertility. Hum Reprod Update. 2006; 12:283-92. [PubMed: 16373403]

55. Hitchins M, Williams R, Cheong K, et al. MLH1 germline epimutations as a factor in hereditary nonpolyposis colorectal cancer. Gastroenterology. 2005; 129:1392-9. [PubMed: 16285940]

56. Krausz C, Forti G, Sassone-Corsi P, Carrell DT. Florence-Utah symposium on the genetics of male infertility. Int J Androl. 2008; 31:373. [PubMed: 18644090]

57. Gonsalves J, Sun F, Schlegel PN, et al. Defective recombination in infertile men. Hum Mol Genet. 2004; 13:2875-83. [PubMed: 15385442]

58. Maduro MR, Casella R, Kim E, et al. Microsatellite instability and defects in mismatch repair proteins: a new aetiology for Sertoli cell-only syndrome. Mol Hum Reprod. 2003; 9:61-8. [PubMed: 12569174]

59. Nudell D, Castillo M, Turek PJ, Pera RR. Increased frequency of mutations in DNA from infertile men with meiotic arrest. Hum Reprod. 2000; 15:1289-94. [PubMed: 10831557]

60. Baker SM, Bronner CE, Zhang L, et al. Male mice defective in the DNA mismatch repair gene PMS2 exhibit abnormal chromosome synapsis in meiosis. Cell. 1995; 82:309-19. [PubMed: 7628019]

61. Lynn A, Koehler KE, Judis L, et al. Covariation of synaptonemal complex length and mammalian meiotic exchange rates. Science. 2002; 296:2222-5. [PubMed: 12052900]

62. Baker SM, Plug AW, Prolla TA, et al. Involvement of mouse Mlh1 in DNA mismatch repair and meiotic crossing over. Nat Genet. 1996; 13:336-42. [PubMed: 8673133]

63. Moens PB, Kolas NK, Tarsounas M, et al. The time course and chromosomal localization of recombination-related proteins at meiosis in the mouse are compatible with models that can resolve the early DNA-DNA interactions without reciprocal recombination. J Cell Sci. 2002; 115:1611-22. [PubMed: 11950880]

64. Judis L, Chan ER, Schwartz S, et al. Meiosis I arrest and azoospermia in an infertile male explained by failure of formation of a component of the synaptonemal complex. Fertil Steril. 2004; 81:205-9. [PubMed: 14711569]

65. Marcon E, Moens P. MLH1p and MLH3p localize to precociously induced chiasmata of okadaicacid-treated mouse spermatocytes. Genetics. 2003; 165:2283-7. [PubMed: 14704203]

66. Wei K, Clark AB, Wong E, et al. Inactivation of Exonuclease 1 in mice results in DNA mismatch repair defects, increased cancer susceptibility, and male and female sterility. Genes Dev. 2003; 17:603-14. [PubMed: 12629043]

67. Sun F, Greene C, Turek PJ, et al. Immunofluorescent synaptonemal complex analysis in azoospermic men. Cytogenet Genome Res. 2005; 111:366-70. [PubMed: 16192718] 
68. Norris AM, Woodruff RD, D'Agostino RB Jr, et al. Elevated levels of the mismatch repair protein PMS2 are associated with prostate cancer. Prostate. 2007; 67:214-25. [PubMed: 17044039]

69. Norris AM, Gentry M, Peehl DM, et al. The elevated expression of a mismatch repair protein is a predictor for biochemical recurrence after radical prostatectomy. Cancer Epidemiol Biomarkers Prev. 2009; 18:57-64. [PubMed: 19124481]

70. McMullin RP, Mutton LN, Bieberich CJ. Hoxb13 regulatory elements mediate transgene expression during prostate organogenesis and carcinogenesis. Dev Dyn. 2009; 238:664-72. [PubMed: 19191217]

71. Nathanson KL, Kanetsky PA, Hawes R, et al. The Y deletion gr/gr and susceptibility to testicular germ cell tumor. Am J Hum Genet. 2005; 77:1034-43. [PubMed: 16380914]

72. Bianchi NO, Richard SM, Pavicic W. Y chromosome instability in testicular cancer. Mutat Res. 2006; 612:172-88. [PubMed: 16483836]

73. Ferlin A, Raicu F, Gatta V, et al. Male infertility: role of genetic background. Reprod Biomed Online. 2007; 14:734-45. [PubMed: 17579990]

74. Vogt PH, Edelmann A, Kirsch S, et al. Human Y chromosome azoospermia factors (AZF) mapped to different subregions in Yq11. Hum Mol Genet. 1996; 5:933-43. [PubMed: 8817327]

75. Reijo R, Alagappan RK, Patrizio P, Page DC. Severe oligozoospermia resulting from deletions of azoospermia factor gene on Y chromosome. Lancet. 1996; 347:1290-3. [PubMed: 8622504]

76. Kostiner DR, Turek PJ, Reijo RA. Male infertility: analysis of the markers and genes on the human Y chromosome. Hum Reprod. 1998; 13:3032-8. [PubMed: 9853850]

77. Kleiman SE, Bar-Shira Maymon B, Yogev L, et al. The prognostic role of the extent of Y microdeletion on spermatogenesis and maturity of Sertoli cells. Hum Reprod. 2001; 16:399-402. [PubMed: 11228202]

78. Lau YF, Zhang J. Expression analysis of thirty one Y chromosome genes in human prostate cancer. Mol Carcinog. 2000; 27:308-21. [PubMed: 10747295]

79. Krausz C, Guarducci E, Becherini L, et al. The clinical significance of the POLG gene polymorphism in male infertility. J Clin Endocrinol Metab. 2004; 89:4292-7. [PubMed: 15356024]

80. Rajender S, Avery K, Agarwal A. Epigenetics, spermatogenesis and male infertility. Mutat Res. 727:62-71. [PubMed: 21540125]

81. Qiao D, Zeeman AM, Deng W, et al. Molecular characterization of hiwi, a human member of the piwi gene family whose overexpression is correlated to seminomas. Oncogene. 2002; 21:3988-99. [PubMed: 12037681]

82. Cox DN, Chao A, Baker J, et al. A novel class of evolutionarily conserved genes defined by piwi are essential for stem cell self-renewal. Genes Dev. 1998; 12:3715-27. [PubMed: 9851978]

83. Jeronimo C, Bastian PJ, Bjartell A, et al. Epigenetics in Prostate Cancer: Biologic and Clinical Relevance. Eur Urol.

84. Skinner MK, Guerrero-Bosagna C. Environmental signals and transgenerational epigenetics. Epigenomics. 2009; 1:111-117. [PubMed: 20563319]

85. Phillips KP, Tanphaichitr N. Human exposure to endocrine disrupters and semen quality. J Toxicol Environ Health B Crit Rev. 2008; 11:188-220. [PubMed: 18368553]

86. Prins GS. Endocrine disruptors and prostate cancer risk. Endocr Relat Cancer. 2008; 15:649-56. [PubMed: 18524946]

87. Xu X, Dailey AB, Talbott EO, et al. Associations of serum concentrations of organochlorine pesticides with breast cancer and prostate cancer in U.S. adults. Environ Health Perspect. 118:606. [PubMed: 20056587]

88. Byar DP, Mostofi FK. Cancer of the prostate in men less than 50 years old: an analysis of 51 cases. J Urol. 1969; 102:726-33. [PubMed: 5372026]

89. Breslow N, Chan CW, Dhom G, et al. Latent carcinoma of prostate at autopsy in seven areas. The International Agency for Research on Cancer, Lyons, France. Int J Cancer. 1977; 20:680-8. [PubMed: 924691]

90. Rullis I, Shaeffer JA, Lilien OM. Incidence of prostatic carcinoma in the elderly. Urology. 1975; 6:295-7. [PubMed: 1172317] 


\section{Fatherhood Status and Prostate Cancer Risk}

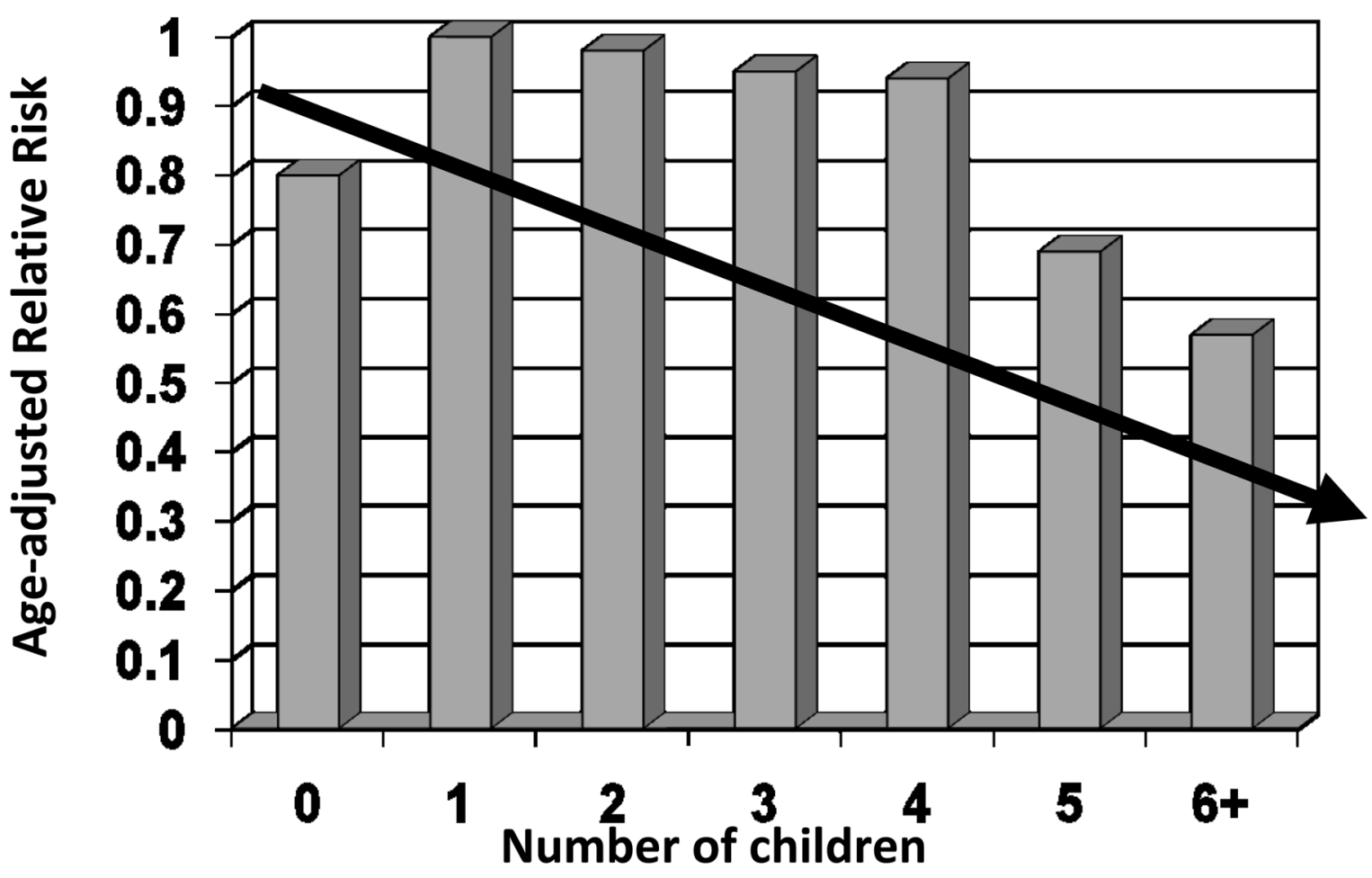

Adapted from: Jorgensen et al. Cancer 112(4): 919-23, 2008

Figure 1.

The number of children sired by a man as a predictor of the age-adjusted relative risk of prostate cancer.

Data from [25] 
Table 2

Epidemiologic Studies of the Association Between Offspring Gender and Prostate Cancer

\begin{tabular}{|l|l|l|l|c|}
\hline Author & Year & Country & Sex Ratio (M:F) & Association between offspring gender and prostate cancer \\
\hline Hill[27] & 1985 & Canadian & 0.565 & Yes \\
\hline Le Marchand [28] & 1986 & U.S. & 0.512 & No \\
\hline Spitz[29] & 1986 & Canadian & 0.500 & No \\
\hline Harlap[30] & 2007 & Jewish Israeli & 0.486 & Yes \\
\hline James[31] & 2007 & White U.S. & 0.487 & No \\
\hline Bermejo[32] & 2007 & Swedish & 0.51 & No \\
\hline Eisenberg[26] & 2010 & U.S. & 0.51 & Yes \\
\hline
\end{tabular}

